\title{
Milk fatty acid variability and association with polymorphisms in SCD1 and DGAT1 genes in White Fulani and Borgou cattle breeds
}

\author{
Isidore Houaga ${ }^{1,2} \cdot$ Anne W. T. Muigai $^{3} \cdot$ Fredrick M. Ng'ang'a ${ }^{4}$ - Eveline M. Ibeagha-Awemu ${ }^{5} \cdot$ Martina Kyallo $^{4}$. \\ Issaka A. K. Youssao ${ }^{2} \cdot$ Francesca Stomeo $^{4}$
}

Received: 4 April 2018 / Accepted: 23 August 2018 / Published online: 30 August 2018

(C) The Author(s) 2018

\begin{abstract}
The stearoyl-CoA desaturase 1 (SCD1) A293V and acyl CoA: diacylglycerol acyltransferase 1 (DGATl) K232A polymorphisms have been associated with significant variation in bovine milk fatty acid composition and unsaturation indices in western cattle breeds. This study aimed to estimate the milk fatty acid variability in indigenous Borgou and White Fulani cattle breeds of Benin, and the effects of the SCD1 A293V and DGAT1 K232A polymorphisms on milk and fatty acid composition and unsaturation indices. Thus, 85 Borgou and 96 White Fulani cows were genotyped for the SCD1 A293V and DGAT1 K232A polymorphisms and their milk and fatty acid composition and unsaturation indices were determined. Borgou presented milk with higher linoleic acid $(\mathrm{P}<0.001)$, oleic acid $(\mathrm{P}<0.05), \mathrm{C} 18$ index $(\mathrm{P}<0.001)$, total unsaturation index $(\mathrm{P}<0.05)$, and lower total saturated fatty acid (SFA) compared to White Fulani. The SCD1 VV genotype was associated with higher protein and lactose contents in White Fulani $(\mathrm{P}<0.05)$. In Borgou, the SCD1 AV genotype was associated with higher $\mathrm{C} 14$ and total unsaturation indices $(\mathrm{P}<0.01)$, while the $S C D 1 \mathrm{~V}$ allele was associated with decrease in $\mathrm{C} 14$ index $(\mathrm{P}<0.05)$. In White Fulani, the SCDI VV genotype was associated with lower $\mathrm{C} 18: 1$ cis-9 content $(\mathrm{P}<0.05)$ while the $D G A T 1 \mathrm{~K}$ allele was associated with increased total SFA $(\mathrm{P}<0.05)$, and decreased $\mathrm{C} 18$ index $(\mathrm{P}<0.05)$, total unsaturation index $(\mathrm{P}<0.01)$ and total monounsaturated fatty acid $(\mathrm{P}<0.01)$. The $S C D 1 \mathrm{~A} 293 \mathrm{~V}$ and DGAT1 K232A may serve as genetic markers to improve milk fatty acid traits in Borgou and White Fulani breeds.
\end{abstract}

Keywords Milk fatty acid variability $\cdot S C D 1 \cdot D G A T 1 \cdot$ Borgou $\cdot$ White Fulani $\cdot$ Benin

Electronic supplementary material The online version of this article (https://doi.org/10.1007/s11033-018-4331-4) contains supplementary material, which is available to authorized users.

Isidore Houaga

houaga.isidore@student.jkuat.ac.ke; ihouaga@gmail.com

Anne W. T. Muigai

awmuigai@fsc.jkuat.ac.ke

Fredrick M. Ng'ang'a

F.Nganga@cgiar.org

Eveline M. Ibeagha-Awemu

Eveline.Ibeagha-Awemu@agr.gc.ca

Martina Kyallo

M.Kyalo@cgiar.org

Issaka A. K. Youssao

issaka.youssao@epac.uac.bj

Francesca Stomeo

F.Stomeo@cgiar.org

\section{Abbreviations}

AMDIS Automated mass spectral deconvolution and identification system

AOAC Association of analytical communities

DGAT1 Acyl CoA: diacylglycerol acyltransferase 1

1 Department of Molecular Biology and Biotechnology, Pan African University Institute of Basic Sciences, Technology and Innovation, PAUSTI-JKUAT, P.O. Box 62000-200, Nairobi, Kenya

2 Department of Animal Health and Production, Polytechnic School of Abomey-Calavi University, 01 P.O. Box 2009, Cotonou, Benin

3 Department of Botany, Jomo Kenyatta University of Agriculture and Technology, P.O. Box 62000-200, Nairobi, Kenya

4 Biosciences Eastern and Central Africa-International Livestock Research Institute (BecA-ILRI) Hub, P.O. Box 30709, Nairobi, Kenya

5 Agriculture and Agri-Food Canada, Sherbrooke Research and Development Centre, 2000 Rue College, Sherbrooke, QC J1M 0C8, Canada 


$\begin{array}{ll}\text { GC-MS } & \text { Gas chromatography-mass spectrometry } \\ \text { HWE } & \text { Hardy-Weinberg Equilibrium } \\ \text { MUFA } & \text { Monounsaturated fatty acid } \\ \text { NIST } & \text { National Institute of Standards and Technology } \\ \text { PCA } & \text { Principal components analysis } \\ \text { PCR } & \text { Polymerase chain-reaction } \\ \text { PUFA } & \text { Polyunsaturated fatty acid } \\ \text { RFLP } & \text { Restriction fragment length polymorphism } \\ \text { SCD1 } & \text { Stearoyl-CoA desaturase 1 } \\ \text { SFA } & \text { Saturated fatty acid }\end{array}$

\section{Introduction}

Milk and dairy products are important sources of energy, fat, high quality protein, vitamins, and minerals in human diets [1]. The fatty acids fraction of bovine milk fat is characterized by high amount (50-70\%) of saturated fatty acids (SFA), 20-40\% monounsaturated (MUFA) and low amount (1-5\%) of polyunsaturated fatty acids (PUFA) [2]. Studies show that high quantities of dietary SFAs are associated with an increase in blood cholesterol and, therefore, with increased risk of atherosclerosis and coronary heart diseases in humans [3-5]. On the contrary, high concentrations of PUFAs in blood and tissue lipids is associated with positive benefits on cardiovascular diseases, mental health [6], exert anticancer effects [7] and play important role in preventing and/or treating various immunes disorders such as allergies $[8,9]$.

With regards to human health aspects, increasing unsaturated fatty acids in cow's milk is an important selection goal [10]. The cow milk fatty acids are derived from two sources, the diet and the microbial activity in the rumen [11]. The fatty acids originating from the blood or from de novo fatty acid synthesis can be desaturated in the mammary gland [10]. Thus, the degree of unsaturation of milk fat is designated by a so-called unsaturation index, which is the ratio of the unsaturated product to the sum of the unsaturated product and the saturated substrate [10, 12]. Several studies showed that the variability of fatty acid composition in cow milk is affected by diet, breed, genetics, parity and stage of lactation [12-14]. In ruminant animals, milk fatty acid synthesis is regulated by several important enzymes including stearoyl CoA desaturase 1 (SCDI), acetyl CoA carboxylase, acyltransferases and fatty acid synthase [15]. Polymorphisms in diacylglycerol acyltransferase 1 (DGATI) and $S C D 1$ genes coding for key enzymes in mammary lipid metabolism have been associated with significant proportion of variation in milk fatty acid composition and unsaturation indices in different cattle populations [10, 15-22].

On bovine chromosome 14 , a lysine to alanine mutation in exon $8(\mathrm{~K} 232 \mathrm{~A})$ of DGAT1 gene [23] has been shown to strongly affect milk composition and milk yield in different cattle populations [24-26]. Moreover, the DGAT1 K232A polymorphism has been reported to be strongly associated with milk fatty acid composition in Dutch Holstein Friesian, Italian Brown, Holstein Crossbred and German Holstein dairy cattle breeds [10, 15, 19, 21, 27]. The DGAT1 lysine variant $(D G A T 1 \mathrm{~K})$ was associated with higher saturated fat, a larger content of $\mathrm{C} 16: 0$ and a small fraction of unsaturated $\mathrm{C} 18$ (C18:1 cis $9, \mathrm{C} 18: 1$ cis 11 , $\mathrm{C} 18: 2$ cis $9,12, \mathrm{C} 18: 3$ cis $9,12,15, \mathrm{C} 18: 1$ trans $6, \mathrm{C} 18: 1$ trans 9 and $\mathrm{C} 18: 1$ trans 11$)$ and conjugated linoleic acid and C14:0 in Dutch Holstein Friesian [21]. The DGAT1 A allele was associated with higher $\mathrm{C} 18$, conjugated linoleic acid (CLA) and total unsaturation indices and with lower C10, C12, C14 and C16 indices in Dutch Holstein Friesian cows [10].

The Stearoyl-CoA Desaturase 1 (SCDI) gene is mapped on chromosome 26 in cattle and expressed in a variety of tissues including adipose and mammary tissue [28]. Moreover, the $S C D 1$ enzyme contributes to the desaturation of SFAs into delta-9 unsaturated fatty acids [29]. A single nucleotide polymorphism SNP in exon 5 (C878T) of the SCD1 gene leads to valine substitution by alanine at amino acid position 293 in the mature protein (Ala293Val). The SCD1 A (Ala293) allele was associated with higher $c i s-9 \mathrm{C} 18: 1$ and total monounsaturated content as well as $\mathrm{C} 14: 1 / \mathrm{C} 14$ ratio in Italian Holstein [22]. However, data on the genetic variability of milk fatty acid composition and unsaturation indices are scarce in African indigenous cattle breeds and the few studies on DGAT1 K232A polymorphism in African indigenous cattle did not show association with milk fatty acid composition [30-32]. In the study of Rahmatalla et al. [31], the DGAT1 K232A genotypes showed significant effects on fat content in Sudanese indigenous Kenana and Butana cattle breeds. The study of Houaga et al. [32] mentioned that the DGATI KK genotype was significantly associated with higher fat yield in White Fulani $(\mathrm{P}<0.05)$. However, they did not investigate the milk fatty acid composition.

In Benin, indigenous White Fulani and Borgou cattle breeds are the main milk producers [32]. However, to date, there has been no study on $S C D 1 \mathrm{~A} 293 \mathrm{~V}$ and DGAT1 K232A influence on milk and fatty acid composition and unsaturation indices. Moreover, no detailed data on milk fatty acid composition of these breeds is available. Such data would be useful for gathering knowledge on nutritional value of indigenous cow milk for the dairy industry in Benin and for the opportunity to improve cow's milk fatty acid composition with regards to human health. Therefore, the present study aimed to estimate the milk fatty acid variation in white Fulani and Borgou cattle breeds and the effects of the DGAT1 K232A and SCD1 A293V polymorphisms on milk and fatty acid composition and unsaturation indices. 


\section{Materials and methods}

\section{Sampling}

A total of 85 Borgou and 96 White Fulani indigenous cows were sampled from state owned farms (Betecoucou, Okpara and Samiondji) and privately owned farms in Benin between May-July 2016 (raining season). Blood and milk samples were obtained from three to ten cows per herd from a total of 17 herds. Only cows in lactation were randomly selected and sampled. The map of Benin indicating the sampling sites is presented in Fig. 1. The feeding system was based solely on natural grazing without concentrate supplementation. The cows were milked once a day in the morning. Additional meta data on sampled cows obtained from the livestock keepers and herders following a written consent permitting sampling included: age, lactation stage and parity number. Blood samples were collected from the jugular vein into $10 \mathrm{ml}$ EDTA vacutainer tubes and immediately transported to the laboratory in a cool box containing ice and stored at $-20^{\circ} \mathrm{C}$ until further analysis. Milk samples were aseptically collected into $50 \mathrm{ml}$ falcon tubes each containing one tablet of Bonopol milk preservative (Systems Plus, Canada) and sent to Valacta laboratories (Valacta Laboratories Inc., Canada, http://www.valacta.com) for the analysis of milk components.

\section{Milk component analysis}

Test-day milk fat percent, protein percent, milk urea nitrogen and lactose percent were determined in milk samples with MilkoScan FT 6000 Series mid-range infrared Fourier transform infrared-based spectrometers (Foss, Hillerod, Denmark) by Valacta Laboratories.

\section{Fatty acids analysis and quantification}

The milk samples were prepared for analysis using alkali hydrolysis followed by methylation as described in Association of Analytical Communities (AOAC) Method 991.39 [33]. Briefly, $1 \mathrm{ml}$ of cow milk was transferred into a $15 \mathrm{ml}$ screwcap centrifuge tube in triplicates and $3 \mathrm{ml}$ of $0.5 \mathrm{~N}$
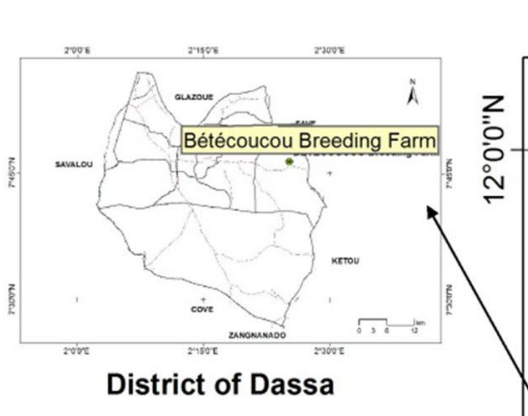

$2^{\circ} 0^{\prime} 0 " \mathrm{E}$

$4^{\circ} 0^{\prime} 0 " \mathrm{E}$

District of Zangnannado

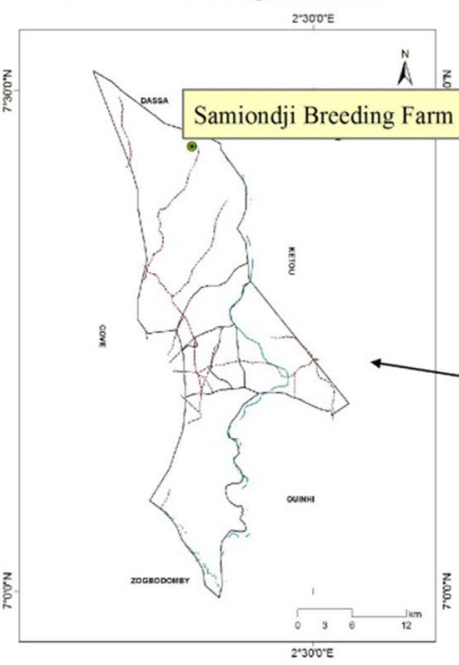

$\hat{A}$
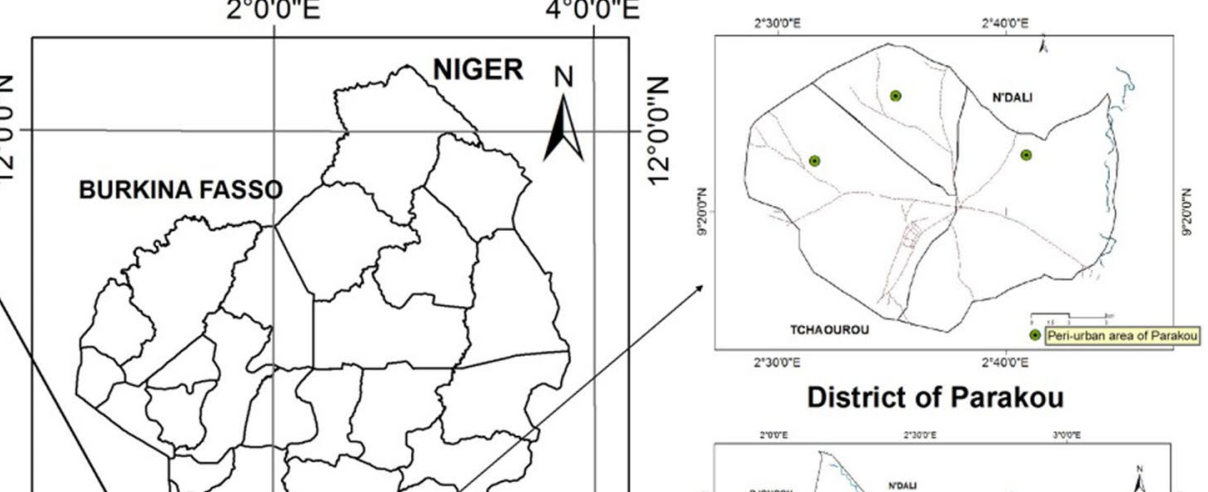

District of Parakou

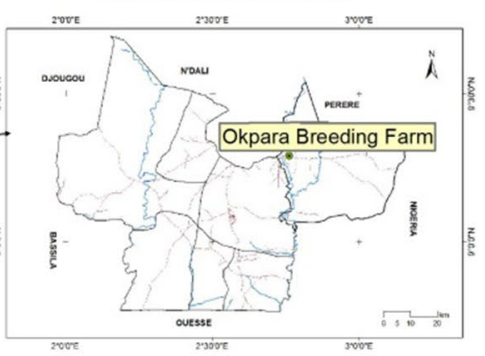

District of TCHAOUROU

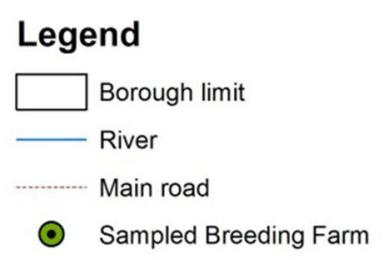

Fig. 1 Map of Benin indicating the sampling sites 
$\mathrm{NaOH}$ in methanol was added into each tube and mixed thoroughly by shaking for $30 \mathrm{~s}$. Tubes were incubated in a water bath at $85{ }^{\circ} \mathrm{C}$ for $10 \mathrm{~min}$ and cooled at ambient temperature. In a fume hood, $1 \mathrm{ml}$ of boron trifluoride $\left(\mathrm{BF}_{3}\right)$ was added, mixed thoroughly by shaking and incubated in a water bath at $85{ }^{\circ} \mathrm{C}$ for $10 \mathrm{~min}$. Samples were allowed to cool to room temperature followed by addition of $3 \mathrm{ml}$ iso-octane and $3 \mathrm{ml}$ of saturated $\mathrm{NaCl}$ solution, mixed by shaking vigorously followed by centrifugation at $2500 \mathrm{rpm}$ for $5 \mathrm{~min}$. The upper layer (iso-octane) containing the fatty acid methyl esters (FAMEs) was transferred through a funnel (cotton wool was placed in the funnel and $1 \mathrm{~g}$ of sodium sulfate $\left(\mathrm{Na}_{2} \mathrm{SO}_{4}\right)$ anhydrous was added on top of the cotton wool) into a test tube with a Pasteur pipette. $2 \mathrm{~g}$ of anhydrous $\mathrm{Na}_{2} \mathrm{SO}_{4}$ was added. The FAMEs were diluted to a volume of $2 \mathrm{ml}$ with hexane in a volumetric flask. $1 \mathrm{ml}$ of the sample was transferred into a screw cap gas chromatography (GC) sample vial and stored at $-20^{\circ} \mathrm{C}$.

The composition of individual FAMEs was analyzed by gas chromatography mass spectrometry (GC-MS). The FAMEs in hexane $(1 \mu \mathrm{l})$ were injected in to a 7890A GC system (Agilent Technologies, USA) coupled to a 240 ion trap mass spectrometer detector (Agilent Technologies) using the Agilent 7693A automatic liquid sampler at a split ratio of 100:1. A VF5-MS (5\% phenyl methylpolysiloxane), $30 \mathrm{~m} \times$ $0.25 \mathrm{~mm}$ id, $0.25 \mu \mathrm{m}$ film capillary column was used with the injector port set at $280{ }^{\circ} \mathrm{C}$. Helium was used as carrier gas at a flow rate of $1 \mathrm{ml} / \mathrm{min}$. The oven temperature was programmed to rise from $50{ }^{\circ} \mathrm{C}$ to $180{ }^{\circ} \mathrm{C}$ at $4{ }^{\circ} \mathrm{C} / \mathrm{min}$ followed by an increase to $250{ }^{\circ} \mathrm{C}$ at $3{ }^{\circ} \mathrm{C} / \mathrm{min}$. The ion trap mass spectrometer parameters were as follow: scan range $50-540(\mathrm{~m} / \mathrm{z})$, ionization mode EI, filament delay time $3 \mathrm{~min}$ and transfer line temperature, manifold temperature and trap temperature of $250^{\circ} \mathrm{C}, 100{ }^{\circ} \mathrm{C}$ and $150^{\circ} \mathrm{C}$, respectively.

Chromatograms and spectra representing individual FAMEs were analyzed using the automated mass spectral deconvolution and identification system software (AMDIS, US). The identification of the individual FAMES was performed by comparing each of the mass spectra with the database of NIST 11 (Gaithersburg, MD, USA) and Wiley $7 \mathrm{~N}$ (John Wiley, NY, USA) and also by comparing the calculated Kovats linear retention indices using retention times of n-alkane series against the values obtained in the NIST webbook for the same capillary column stationery phase [34]. The quantification of individual FAMEs was performed by the peak area percentage method. The fatty acid concentrations were expressed as the ratio of each individual fatty acid to the total of all fatty acids detected in the sample. The fatty acids unsaturation indices were calculated as the ratio of cis- 9 unsaturated to $c i s-9$ unsaturated + saturated for specific fatty acid pairs and multiplied by 100 [12]. We calculated the following indices: $\mathrm{C} 14$ index $=\mathrm{C} 14: 1 \mathrm{cis}-9 /(\mathrm{C} 14: 1 \mathrm{cis}-9+\mathrm{C} 14: 0) \times 100$ and $\mathrm{C} 18$ index $=\mathrm{C} 18: 1 \mathrm{cis}-9 /(\mathrm{C} 18: 1 \mathrm{cis}-9+\mathrm{C} 18: 0) \times 100$. The total index was calculated as total index $=(\mathrm{C} 14: 1$ cis $-9+\mathrm{C} 18: 1$ cis-9)/(C14:1 cis-9+C14:0+C18:1 cis-9+C18:0) $\times 100$ [22].

\section{Genotyping of DGAT1 K232A and SCD1 A293V mutations}

Genomic DNA was isolated from blood samples using the phenol-chloroform method [35]. DNA quality was checked on $0.8 \%$ agarose gel and the quantity was checked using the NanoDrop ND-1000 spectrophotometer (NanoDrop Technologies, Inc., USA). The DGAT1 K232A and SCD1 A293V genotypes were determined by the method of polymerase chain reaction-restriction fragment length polymorphisms (PCR-RFLP) [20, 30].

The primers 5'-GCACCATCCTCTTCCTCAAG-3' (forward) and 5'-GGAAGCGCTTTCGGATG-3' (reverse) [30] were used to amplify a $411 \mathrm{bp}$ fragment of the bovine DGATI gene containing the lysine/alanine substitution (exon 8) while 5'-CCCATTCGCTCTTGTTCTGT-3 (forward) and 5'-CGT GGTCTTGCTGTGGACT-3' (reverse) [20] were used to amplify a $400 \mathrm{bp}$ fragment containing the A293V polymorphism in exon 5 of the $S C D 1$ gene. The PCR reactions were carried out in a $30 \mu \mathrm{l}$ volume containing $45 \mathrm{ng}$ of template DNA, $15 \mu \mathrm{l}$ of PCR Master Mix (Bioneer, Korea) and $4.5 \mathrm{pmol}$ of each primer ( $3 \mathrm{pmol} / \mu \mathrm{l})$. The PCR conditions were as follows: an initial denaturation step at $94{ }^{\circ} \mathrm{C}$ for $3 \mathrm{~min}, 35$ cycles of $94{ }^{\circ} \mathrm{C}$ for $45 \mathrm{~s}, 62{ }^{\circ} \mathrm{C}(D G A T 1 \mathrm{~K} 232 \mathrm{~A})$ or $64{ }^{\circ} \mathrm{C}(S C D 1$ A293V) for $60 \mathrm{~s}, 72^{\circ} \mathrm{C}$ for $60 \mathrm{~s}$, and a final extension step of $72{ }^{\circ} \mathrm{C}$ for $5 \mathrm{~min}$. The PCR reactions were performed in the GeneAmp PCR System 9700 (Applied Biosystems, USA). Amplification was confirmed by running the PCR products on $1.8 \%$ agarose gel and visualized with GelDoc-It ${ }^{2}$ Imager (UltraViolet Products Ltd., UK). The PCR products were purified with the QIA quick PCR Purification Kit (Qiagen, Germany).

Five microliter of purified PCR products containing the DGAT1 K232A were digested overnight at $37{ }^{\circ} \mathrm{C}$ with 10 $\mathrm{U}$ of EaeI restriction enzyme (New England Biolabs, Inc., USA). The digested PCR products were separated on $1.8 \%$ agarose gel stained with GelRed ${ }^{\mathrm{TM}}$ (Biotium, UK) resulting in two fragments of 203 and $208 \mathrm{bp}$ (seen as a single band on gel) for AA genotype, two fragments of 203/208 bp and $411 \mathrm{bp}$ for KA genotype and the undigested $411 \mathrm{bp}$ for KK genotype (Additional file 1: Figure a).

Similarly, $5 \mu \mathrm{l}$ of purified PCR products containing the SCD1 A293V mutation were digested overnight at $37{ }^{\circ} \mathrm{C}$ with $10 \mathrm{U}$ of $\mathrm{NcoI}$ restriction enzyme (New England Biolabs, Inc., USA). The digested products were separated on $1.8 \%$ agarose gel stained with GelRed ${ }^{\mathrm{TM}}$ (Biotium, UK), visualized and scanned with GelDoc-It ${ }^{2}$ Imager (Ultra-Violet Products Ltd., UK). The digestion patterns resulted in two fragments of $200 \mathrm{bp}$ for the AA genotype, undigested $400 \mathrm{bp}$ fragment for the VV genotype and $400 \mathrm{bp}$ and $200 \mathrm{bp}$ fragments for the AV genotypes (Additional file 1: Figure b). 


\section{Statistical analysis}

The allele frequencies and test for Hardy-Weinberg Equilibrium (HWE) were performed with GENEPOP program version 1.2 [36]. To investigate the effect of breed, SCD1 A293V and DGAT1 K232A genotypes on milk fatty acids and milk components, the following mixed linear model with IBM SPSS version 20 software package was used: produced milk with higher content of fat compared to Borgou $(\mathrm{P}<0.001)$. On the other hand, Borgou presented higher content of milk urea nitrogen than White Fulani $(\mathrm{P}<0.001)$. However, no significant differences were observed for protein and lactose contents between the two breeds (Table 1). About fifteen different fatty acids were quantified with confidence in the milks of White Fulani and Borgou breeds, namely caproic acid (C6:0), caprylic

$\mathrm{Y}_{\mathrm{ijklm}}=\mu+\mathrm{B}_{\mathrm{i}}+\mathrm{GD}_{\mathrm{j}}+\mathrm{GS}_{\mathrm{k}}+\left(\mathrm{Bi} \times \mathrm{Gj}_{\mathrm{ij}}+\left(\mathrm{Bi} \times \mathrm{GS}_{\mathrm{k}}\right)_{\mathrm{ik}}+\mathrm{GR}_{\mathrm{l}} \mathrm{A}_{\mathrm{m}}+\mathrm{E}_{\mathrm{ijk} \mathrm{kmn}}\right.$

where $\mathrm{Y}_{\mathrm{ijklmn}}$ is the observed phenotype: fat $\%$, protein $\%$, lactose $\%$, milk urea nitrogen $(\mathrm{mg} / \mathrm{dl})$, individual fatty acid\%, groups of fatty acids (saturated fatty acids [SFA], monounsaturated fatty acids [MUFA], polyunsaturated fatty acids [PUFA]) and unsaturation indices (C14 index, C18 index and total index), $\mu$ is the population mean, $\mathrm{Bi}$ is the fixed effect of Breed, GDj is the fixed effect of DGAT1 genotypes (KK and KA), $\mathrm{GS}_{\mathrm{k}}$ is the fixed effect of $S C D 1$ genotypes $(\mathrm{VV}, \mathrm{AV}) ;(\mathrm{Bi} \times \mathrm{Gj})_{\mathrm{ij}}$ is the fixed interaction effect between breed and DGATl genotypes, $\left(\mathrm{Bi} \times \mathrm{GS}_{\mathrm{k}}\right)_{\mathrm{ik}}$ is the fixed interaction effect between breed and $S C D 1$ genotypes, GR is the geographical region (south and north), $\mathrm{A}_{\mathrm{m}}$ is the random animal effect and $\mathrm{E}_{\mathrm{ijklmn}}$ is the random residual error associated with each record. The age, lactation stage and parity number were included in the initial model and were dropped out from the final model due to the absence of significant effect. The allele substitution effect of DGATI (K variant) and SCDI (V variant) was estimated following the method of Marchitelli et al. [37] by regressing the number of copies of DGAT1 K allele and SCDI V allele against each of the milk fatty acid and milk component traits separately. The phenotypes were nested within breed to obtain breed specific estimates. The results of the different effects are presented as least squares means \pm standard error. The Pearson correlation indices were calculated among the various milk and fatty acids and milk component traits using the IBM SPSS version 20 software package. The principal component analysis (PCA) of the significant milk traits (Fat, protein, C14:1 cis-9, C16:0, C18:2 cis-9, cis-12, C18:1 cis-9, C14 index, C18 index, Total index, SFA, MUFA and PUFA) between breeds was done using Minitab software version 18. Significance was declared at $\mathrm{P}<0.05$.

\section{Results}

\section{Effect of breed on milk component and fatty acid traits}

Least square means of milk components and fatty acid profiles across breeds are reported in Table 1. White Fulani acid (C8:0), capric acid (C10:0), lauric acid (C12:0), 12-methyl tridecanoic acid (C13:0), myristoleic acid (C14:1 cis-9), myristic acid (C14:0), pentadecanoic acid (C15:0), palmitic acid (C16:0), margaric acid (C17:0), linoleic acid (C18:2 cis-9, cis-12), oleic acid (C18:1 cis9), stearic acid (C18:0), nonadecanoic acid (C19:0) and arachidic acid (C20:0). The fatty acid profiles revealed that oleic acid (16.63\%) and linoleic acid (15.84\%) were the most abundant fatty acids in Borgou milk while stearic acid (17.88\%) and palmitic acid (16.19\%) were the most abundant fatty acids in White Fulani milk. The Borgou cows produced milk with higher contents of C8:0, C10:0, C14:0, C15:0, C17:0, C18:2 cis-9, cis-12, C18:1 cis-9, and C19:0 compared to White Fulani cattle breed $(\mathrm{P}<0.05)$. On the other hand, White Fulani produced milk with higher contents of $\mathrm{C} 18: 0$ and $\mathrm{C} 16: 0$ compared to Borgou breed $(\mathrm{P}<0.001)$. Moreover, Borgou had higher C18 unsaturation index, total index and higher contents of PUFA than White Fulani $(\mathrm{P}<0.05)$. On the contrary White Fulani produced milk with higher $(\mathrm{P}<0.001)$ contents of total SFA as compared to Borgou. No significant differences between breeds were observed for C6:0, C12:0, C13:0, C14:1 cis-9, C20:0 and MUFA (Table 1).

The principal component analysis (PCA) of the significant variables (Fat, protein, C14:1 cis-9, C16:0, C18:2 cis9, cis-12, C18:1 cis-9, C14 index, C18 index, Total index, SFA, MUFA and PUFA) between breeds is presented in Fig. 2. The first component (Axis) clearly separated White Fulani from Borgou. The White Fulani population (red) was on the left side and the Borgou (blue) on the right side as shown in Fig. 2. The PCA analysis therefore showed that the two cattle populations are different for the studied milk traits.

\section{Effect of geographical regions}

The effect of geographical regions on milk fatty acid traits is presented in Table 2. Because the White Fulani cattle are only found in the northern part of Benin, only Borgou breed was considered in the geographical effect analysis. The Borgou cows from the South of Benin showed milk 
Table 1 Effect of breed on milk production traits and individual fatty acids composition in Borgou and White Fulani Cows

\begin{tabular}{|c|c|c|c|c|c|}
\hline \multirow[t]{2}{*}{ Trait } & \multicolumn{4}{|l|}{ Breed } & \multirow[t]{2}{*}{ P-value } \\
\hline & Borgou (85) & SEM & White Fulani (96) & SEM & \\
\hline \multicolumn{6}{|l|}{ Milk production traits } \\
\hline Fat $(\%)$ & 4.51 & 0.19 & 5.49 & 0.19 & $<\mathbf{0 . 0 0 1}$ \\
\hline Protein $(\%)$ & 3.76 & 0.06 & 3.8 & 0.06 & 0.620 \\
\hline Milk urea nitrogen (mg/dl) & 10.33 & 0.33 & 8.04 & 0.33 & $<\mathbf{0 . 0 0 1}$ \\
\hline Lactose (\%) & 4.45 & 0.04 & 4.48 & 0.04 & 0.586 \\
\hline \multicolumn{6}{|l|}{ Fatty acids and unsaturation indices (\%) } \\
\hline Caproic acid (C6:0) & 0.29 & 0.04 & 0.23 & 0.03 & 0.268 \\
\hline Caprylic acid (C8:0) & 0.42 & 0.04 & 0.31 & 0.04 & 0.042 \\
\hline Capric acid (C10:0) & 1.15 & 0.08 & 0.93 & 0.07 & 0.047 \\
\hline Lauric acid (C12:0) & 1.57 & 0.11 & 1.46 & 0.11 & 0.470 \\
\hline 12-Methyl tridecanoic acid (C13:0) & 0.37 & 0.04 & 0.34 & 0.04 & 0.735 \\
\hline Myristoleic acid (C14:1 cis-9) & 1.02 & 0.08 & 0.87 & 0.08 & 0.210 \\
\hline Myristic acid (C14:0) & 12.19 & 0.60 & 9.07 & 0.57 & $<\mathbf{0 . 0 0 1}$ \\
\hline Pentadecanoic acid (C15:0) & 4.29 & 0.24 & 2.62 & 0.23 & $<\mathbf{0 . 0 0 1}$ \\
\hline Palmitic acid (C16:0) & 5.27 & 0.95 & 16.19 & 0.89 & $<0.001$ \\
\hline Margaric acid (C17:0) & 7.34 & 0.36 & 3.67 & 0.34 & $<0.001$ \\
\hline Linoleic acid (C18:2 cis-9, cis-12) & 15.84 & 0.64 & 9.85 & 0.60 & $<0.001$ \\
\hline Oleic acid (C18:1 cis-9) & 16.63 & 0.84 & 14.25 & 0.79 & 0.042 \\
\hline Stearic acid (C18:0) & 12.96 & 0.90 & 17.86 & 0.84 & $<\mathbf{0 . 0 0 1}$ \\
\hline Nonadecanoic acid (C19:0) & 0.96 & 0.13 & 0.53 & 0.13 & 0.019 \\
\hline Arachidic acid (C20:0) & 0.20 & 0.03 & 0.24 & 0.03 & 0.207 \\
\hline C14 index ${ }^{a}$ & 9.69 & 1.17 & 8.48 & 1.10 & 0.452 \\
\hline C18 index $^{b}$ & 55.61 & 2.11 & 45.37 & 1.98 & $<0.001$ \\
\hline Total index ${ }^{c}$ & 40.78 & 1.72 & 35.66 & 1.62 & $\mathbf{0 . 0 3 1}$ \\
\hline \multicolumn{6}{|l|}{ Fatty acid groups (\%) } \\
\hline SFA & 58.46 & 1.03 & 68.19 & 0.97 & $<0.001$ \\
\hline MUFA & 21.98 & 1.09 & 19.41 & 1.03 & 0.088 \\
\hline PUFA & 19.56 & 0.77 & 12.40 & 0.72 & $<\mathbf{0 . 0 0 1}$ \\
\hline
\end{tabular}

Bold in the table indicates P-values lower than 0.05

SFA saturated fatty acid, MUFA monounsaturated fatty acid, PUFA polyunsaturated fatty acid, SEM standard errors of the means

${ }^{\mathrm{a}} \mathrm{C} 14$ index $=\mathrm{C} 14: 1$ cis- $9 /(\mathrm{C} 14: 1$ cis $-9+\mathrm{C} 14: 0) \times 100$

${ }^{\mathrm{b}} \mathrm{C} 18$ index $=\mathrm{C} 18: 1 \mathrm{cis}-9 /(\mathrm{C} 18: 1 \mathrm{cis}-9+\mathrm{C} 18: 0) \times 100$

${ }^{\mathrm{c}}$ Total index $=(\mathrm{C} 14: 1$ cis-9 $+\mathrm{C} 18: 1$ cis-9) $/(\mathrm{C} 14: 1$ cis-9 $+\mathrm{C} 14: 0+\mathrm{C} 18: 1$ cis-9 $+\mathrm{C} 18: 0) \times 100$ with higher contents of C12:0, C18:2 cis-9, cis-12 and PUFA $(\mathrm{P}<0.05)$. However, the Borgou cows from the North of Benin produced milk with higher contents of C14:1 cis-9, C18:1 cis-9, MUFA, and higher C14 index, $\mathrm{C} 18$ index and total index compared to Borgou cows from the South of Benin $(\mathrm{P}<0.05)$.

\section{Effects of SCD1 A293V polymorphism on milk traits}

The frequencies of $293 \mathrm{~V}$ were 0.84 and 0.94 in Borgou and White Fulani respectively, and the genotypes were in Hardy-Weinberg equilibrium (Table 3). Only four Borgou cows and one White Fulani cow were of AA genotype. The AA genotype was therefore not included in the association analysis. The $S C D 1 \mathrm{VV}$ genotype was associated with higher $(\mathrm{P}<0.05)$ protein and lactose contents and lower $(\mathrm{P}<0.05)$ C18:1 cis-9 content in White Fulani (Table 4). On the other hand, the SCD1 AV genotype was associated with higher $(\mathrm{P}<0.01) \mathrm{C} 14$ index and total index compared to the VV genotype in Borgou (Table 4).

The estimates of the SCD1 293V allele substitution effect in Borgou breed are presented in Table 5. In comparison to the $\mathrm{A}$ allele, the $\mathrm{V}$ allele was associated with decrease in $\mathrm{C} 14$ index $(-5.68 \%, \mathrm{P}<0.05)$. However, no 


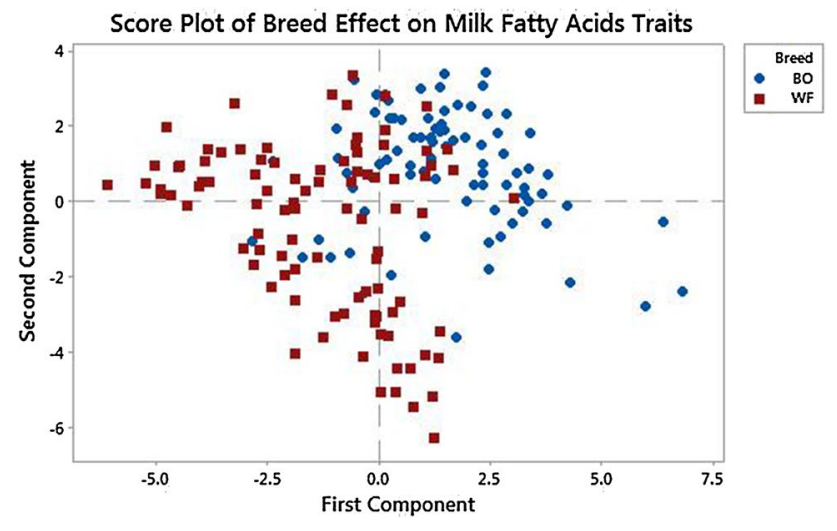

Fig. 2 Principal component analysis of milk component and fatty acids traits in Borgou (BO) and White Fulani (WF) cows. The first component grouped most of the variables from White Fulani on the left side and Borgou on the right side

significant $293 \mathrm{~V}$ allele substitution effect was observed for C18 and total indices, and MUFA in Borgou (Table 5).

\section{Effects of the DGAT1 K232A polymorphism}

The frequencies of $232 \mathrm{~K}$ were 0.77 and 0.92 in Borgou and White Fulani respectively, and the genotypes were in Hardy-Weinberg equilibrium (Table 3). The DGAT1 K232A polymorphism did not significantly affect milk composition, fatty acid profiles and unsaturation indices in Borgou breed and White Fulani (Additional file 2: Table S1). However, the P-values for C14:0, C15:0 and $\mathrm{C} 19: 0$ tended towards significance $(\mathrm{P}<0.1)$ in Borgou where the DGATl KK genotype seems to show higher C14:0 and C15:0, and lower C19:0 contents (Additional file 2: Table S1). However, allele substitution effects indicated that the DGAT1 $232 \mathrm{~K}$ allele was associated with increased total saturated fatty acid (SFA, $+5.41 \%$, $\mathrm{P}<0.05)$, and with decreased $\mathrm{C} 18$ index $(-12.16 \%$, $\mathrm{P}<0.05)$, total index $(-12.81 \%, \mathrm{P}<0.01)$ and MUFA $(-8.09 \%, \mathrm{P}<0.01)$ in White Fulani breed (Table 5).
Table 2 Effect of geographical regions on milk fatty acids composition traits in Borgou

\begin{tabular}{|c|c|c|c|c|c|}
\hline \multirow[t]{2}{*}{ Trait $(\%)$} & \multicolumn{4}{|c|}{ Geographical region } & \multirow[t]{2}{*}{ P-value } \\
\hline & South (32) & SEM & North (53) & SEM & \\
\hline Caproic acid (C6:0) & 0.23 & 0.05 & 0.32 & 0.04 & 0.117 \\
\hline Caprylic acid (C8:0) & 0.33 & 0.07 & 0.48 & 0.05 & 0.068 \\
\hline Capric acid (C10:0) & 1.18 & 0.12 & 1.12 & 0.09 & 0.717 \\
\hline Lauric acid (C12:0) & 2.07 & 0.19 & 1.27 & 0.15 & 0.002 \\
\hline 12-Methyl tridecanoic acid (C13:0) & 0.36 & 0.08 & 0.37 & 0.06 & 0.944 \\
\hline Myristoleic acid (C14:1 cis-9) & 0.70 & 0.12 & 1.21 & 0.09 & 0.001 \\
\hline Myristic acid (C14:0) & 12.88 & 0.99 & 11.78 & 0.77 & 0.387 \\
\hline Pentadecanoic acid (C15:0) & 4.00 & 0.49 & 4.46 & 0.38 & 0.454 \\
\hline Palmitic acid (C16:0) & 5.76 & 1.43 & 4.98 & 1.11 & 0.667 \\
\hline Margaric acid (C17:0) & 7.72 & 0.71 & 7.11 & 0.55 & 0.492 \\
\hline Linoleic acid (C18:2 cis-9-12) & 17.48 & 1.03 & 14.85 & 0.80 & 0.046 \\
\hline Oleic acid (C18:1 cis-9) & 13.69 & 1.13 & 18.40 & 0.88 & 0.001 \\
\hline Stearic acid (C18:0) & 13.35 & 0.88 & 12.72 & 0.69 & 0.569 \\
\hline Nonadecanoic acid (C19:0) & 0.79 & 0.27 & 1.06 & 0.21 & 0.436 \\
\hline Arachidic acid (C20:0) & 0.21 & 0.04 & 0.19 & 0.03 & 0.761 \\
\hline C14 inde ${ }^{a}$ & 5.01 & 2.56 & 12.52 & 1.99 & $\mathbf{0 . 0 2 3}$ \\
\hline C18 index ${ }^{b}$ & 50.83 & 2.38 & 58.50 & 1.85 & 0.012 \\
\hline Total index ${ }^{c}$ & 55.84 & 3.86 & 71.02 & 3.00 & 0.003 \\
\hline SFA & 60.63 & 1.58 & 57.15 & 1.22 & 0.086 \\
\hline MUFA & 17.87 & 1.43 & 24.46 & 1.11 & $<0.001$ \\
\hline PUFA & 21.50 & 1.22 & 18.39 & 0.95 & 0.046 \\
\hline
\end{tabular}

Bold in the table indicates P-values lower than 0.05

$S F A$ saturated fatty acid, MUFA monounsaturated fatty acid, PUFA polyunsaturated fatty acid, SEM standard errors of the means

${ }^{\mathrm{a}} \mathrm{C} 14$ index $=\mathrm{C} 14: 1$ cis-9/(C14:1 cis-9+C14:0) $\times 100$

${ }^{\mathrm{b}} \mathrm{C} 18$ index $=\mathrm{C} 18: 1 \mathrm{cis}-9 /(\mathrm{C} 18: 1 \mathrm{cis}-9+\mathrm{C} 18: 0) \times 100$

${ }^{\mathrm{c}}$ Total index $=(\mathrm{C} 14: 1$ cis $-9+\mathrm{C} 18: 1$ cis-9) $/(\mathrm{C} 14: 1$ cis- $-9+\mathrm{C} 14: 0+\mathrm{C} 18: 1$ cis- $9+\mathrm{C} 18: 0) \times 100$ 
Table 3 Allele and genotype frequencies for SCD1 A293V and DGAT1 K232A polymorphisms in Borgou and White Fulani cows

\begin{tabular}{|c|c|c|c|c|c|c|c|}
\hline \multirow[t]{2}{*}{ Gene } & \multirow[t]{2}{*}{ Breed } & \multicolumn{3}{|c|}{ Genotype frequencies } & \multicolumn{2}{|c|}{ Allele frequencies } & \multirow[t]{2}{*}{ Chi-square } \\
\hline & & VV & AV & AA & $\mathrm{V}$ & A & \\
\hline \multirow[t]{3}{*}{ SCD1 A293V } & Borgou (85) & 61 & 20 & 4 & 0.84 & 0.16 & 1.78 \\
\hline & White Fulani (96) & 85 & 10 & 1 & 0.94 & 0.06 & 1.19 \\
\hline & & KK & KA & AA & $\mathrm{K}$ & A & \\
\hline \multirow[t]{2}{*}{ DGAT1 K232A } & Borgou $(83)^{\mathrm{a}}$ & 48 & 31 & 4 & 0.77 & 0.23 & 0.13 \\
\hline & White Fulani (96) & 81 & 14 & 1 & 0.92 & 0.08 & 0.2 \\
\hline
\end{tabular}

Numbers in brackets correspond to sample size

a2 Borgou cows could not be genotyped for DGAT1 K232 polymorphism

${ }^{\mathrm{b}}$ Critical Chi square at 1 degree of freedom is 3.84

Table 4 Effect of SCD1 A293V genotypes on milk components and fatty acids traits in White Fulani and Borgou cattle breeds

\begin{tabular}{|c|c|c|c|c|c|c|c|}
\hline \multirow[t]{2}{*}{ Trait } & \multicolumn{3}{|c|}{ SCD1 genotypes in White Fulani } & \multicolumn{3}{|c|}{ SCD1 genotypes in Borgou } & \multirow[t]{2}{*}{ P-value } \\
\hline & $\begin{array}{l}\mathrm{VV} \pm \mathrm{SE} \\
(\mathrm{n}=84)\end{array}$ & $\begin{array}{l}\mathrm{AV} \pm \mathrm{SE} \\
(\mathrm{n}=10)\end{array}$ & P-value & $\begin{array}{l}\mathrm{VV} \pm \mathrm{SE} \\
(\mathrm{n}=61)\end{array}$ & $\begin{array}{l}\mathrm{AV} \pm \mathrm{SE} \\
(\mathrm{n}=20)\end{array}$ & $\begin{array}{l}\mathrm{AA} \pm \mathrm{SE} \\
(\mathrm{n}=4)\end{array}$ & \\
\hline \multicolumn{8}{|l|}{ Milk production traits } \\
\hline Fat $(\%)$ & $4.82 \pm 0.19$ & $4.80 \pm 0.53$ & 0.887 & $4.74 \pm 0.28$ & $5.7 \pm 0.49$ & $3.25 \pm 1.09$ & 0.075 \\
\hline Protein $(\%)$ & $3.90 \pm 0.09$ & $3.2 \pm 0.25$ & 0.023 & $3.84 \pm 0.11$ & $4.05 \pm 0.20$ & $3.50 \pm 0.44$ & 0.438 \\
\hline Lactose $(\%)$ & $4.84 \pm 0.04$ & $4.60 \pm 0.12$ & 0.024 & $4.44 \pm 0.12$ & $4.65 \pm 0.13$ & $4.83 \pm 0.28$ & 0.282 \\
\hline \multicolumn{8}{|l|}{ Fatty acids and unsaturation indices (\%) } \\
\hline Caproic acid (C6:0) & $0.25 \pm 0.04$ & $0.07 \pm 0.12$ & 0.366 & $0.25 \pm 0.03$ & $0.43 \pm 0.06$ & $0.13 \pm 0.12$ & 0.010 \\
\hline Caprylic acid (C8:0) & $0.10 \pm 0.03$ & $0.00 \pm 0.08$ & 0.573 & $0.38 \pm 0.05$ & $0.59 \pm 0.08$ & $0.21 \pm 0.18$ & 0.040 \\
\hline Capric acid (C10:0) & $0.50 \pm 0.09$ & $0.30 \pm 0.27$ & 0.671 & $1.14 \pm 0.08$ & $1.25 \pm 0.15$ & $0.76 \pm 0.33$ & 0.384 \\
\hline Lauric acid (C12:0) & $0.94 \pm 0.11$ & $0.50 \pm 0.32$ & 0.300 & $1.68 \pm 0.15$ & $1.28 \pm 0.26$ & $1.35 \pm 0.58$ & 0.386 \\
\hline 12-Methyl tridecanoic acid (C13:0) & $0.10 \pm 0.04$ & $0.00 \pm 0.10$ & 0.646 & $0.38 \pm 0.06$ & $0.32 \pm 0.1$ & $0.35 \pm 0.22$ & 0.839 \\
\hline Myristoleic acid (C14:1 cis-9) & $0.45 \pm 0.09$ & $0.10 \pm 0.25$ & 0.365 & $0.95 \pm 0.09$ & $1.31 \pm 0.16$ & $0.58 \pm 0.35$ & 0.065 \\
\hline Myristic acid (C14:0) & $4.10 \pm 0.27$ & $5.10 \pm 0.80$ & 0.469 & $12.54 \pm 0.72$ & $11.66 \pm 1.26$ & $9.6 \pm 2.82$ & 0.536 \\
\hline Pentadecanoic acid (C15:0) & $2.13 \pm 0.18$ & $1.80 \pm 0.53$ & 0.682 & $4.13 \pm 0.35$ & $4.97 \pm 0.62$ & $3.27 \pm 1.38$ & 0.379 \\
\hline Palmitic acid (C16:0) & $2.14 \pm 0.23$ & $1.30 \pm 0.65$ & 0.478 & $5.46 \pm 1.01$ & $3.05 \pm 1.76$ & $13.60 \pm 3.94$ & 0.053 \\
\hline Margaric acid (C17:0) & $2.82 \pm 0.25$ & $3.10 \pm 0.72$ & 0.434 & $7.01 \pm 0.51$ & $8.56 \pm 0.89$ & $6.26 \pm 1.99$ & 0.278 \\
\hline Linoleic acid (C18:2 cis-9, cis-12) & $3.44 \pm 0.29$ & $3.30 \pm 0.83$ & 0.650 & $16.09 \pm 0.76$ & $15.11 \pm 1.34$ & $15.70 \pm 2.98$ & 0.815 \\
\hline Oleic acid (C18:1 cis-9) & $2.92 \pm 0.27$ & $3.70 \pm 0.78$ & 0.039 & $16.08 \pm 0.85$ & $19.14 \pm 1.48$ & $12.43 \pm 3.32$ & 0.093 \\
\hline Stearic acid (C18:0) & $2.82 \pm 0.26$ & $2.40 \pm 0.74$ & 0.821 & $13.32 \pm 0.64$ & $11.65 \pm 1.11$ & $13.87 \pm 2.49$ & 0.400 \\
\hline Nonadecanoic acid (C19:0) & $0.19 \pm 0.09$ & $0.00 \pm 0.79$ & 0.753 & $0.88 \pm 0.20$ & $1.05 \pm 0.35$ & $1.78 \pm 0.77$ & 0.512 \\
\hline Arachidic acid (C20:0) & $0.03 \pm 0.02$ & $0.00 \pm 0.05$ & 0.878 & $0.19 \pm 0.03$ & $0.16 \pm 0.05$ & $0.45 \pm 0.11$ & 0.062 \\
\hline C14 index ${ }^{\mathrm{a}}$ & $8.80 \pm 0.54$ & $6.10 \pm 1.57$ & 0.269 & $6.93^{\mathrm{a}} \pm 1.81$ & $18.94^{b} \pm 3.15$ & $5.57^{\mathrm{a}} \pm 7.05$ & 0.005 \\
\hline C18 index ${ }^{b}$ & $46.59 \pm 2.53$ & $39.77 \pm 7.35$ & 0.515 & $54.71 \pm 1.77$ & $59.85 \pm 3.09$ & $48.22 \pm 6.90$ & 0.199 \\
\hline Total index ${ }^{c}$ & $36.56 \pm 2.00$ & $31.46 \pm 5.80$ & 0.598 & $61.64^{\mathrm{a}} \pm 2.80$ & $78.79^{\mathrm{b}} \pm 4.89$ & $53.79^{\mathrm{a}} \pm 10.94$ & 0.007 \\
\hline SFA & $67.96 \pm 1.08$ & $68.56 \pm 3.14$ & 0.968 & $47.36 \pm 0.88$ & $44.96 \pm 1.54$ & $51.61 \pm 3.44$ & 0.161 \\
\hline MUFA & $20.02 \pm 1.21$ & $16.36 \pm 3.52$ & 0.499 & $17.03 \pm 0.86$ & $20.45 \pm 1.50$ & $13.02 \pm 3.35$ & 0.058 \\
\hline PUFA & $12.02 \pm 0.78$ & $15.08 \pm 2.26$ & 0.332 & $16.09 \pm 0.76$ & $15.11 \pm 1.34$ & $15.70 \pm 2.98$ & 0.815 \\
\hline
\end{tabular}

Bold in the table indicates P-values lower than 0.05

SCD1 AA genotype was not included in the analysis for While Fulani because only one individual of White Fulani breed was AA. Means with different superscript letters across genotypes differ significantly

SFA saturated fatty acid, MUFA monounsaturated fatty acid, PUFA polyunsaturated fatty acid, $S E$ standard error of the mean

${ }^{\mathrm{a}} \mathrm{C} 14$ index $=\mathrm{C} 14: 1 \mathrm{cis}-9 /(\mathrm{C} 14: 1 \mathrm{cis}-9+\mathrm{C} 14: 0) \times 100$

${ }^{\mathrm{b}} \mathrm{C} 18$ index $=\mathrm{C} 18: 1 \mathrm{cis}-9 /(\mathrm{C} 18: 1 \mathrm{cis}-9+\mathrm{C} 18: 0) \times 100$

${ }^{\mathrm{c}}$ Total index $=(\mathrm{C} 14: 1$ cis $-9+\mathrm{C} 18: 1$ cis-9)/(C14:1 cis-9+C14:0+C18:1 cis-9+C18:0) $\times 100$ 
Table 5 Effect of $S C D 1 \mathrm{~V}$ and $D G A T 1 \mathrm{~K}$ alleles substitution on fatty acids unsaturation in Borgou and White Fulani cattle breeds respectively

\begin{tabular}{|c|c|c|c|c|c|c|}
\hline \multirow[t]{2}{*}{ Traits } & \multicolumn{2}{|c|}{ SCD1 V (Borgou) } & \multirow[t]{2}{*}{$\mathrm{P}$-value } & \multicolumn{2}{|c|}{ DGAT1 K (White Fulani) } & \multirow[t]{2}{*}{ P-value } \\
\hline & Estimates & SEM & & Estimates & SEM & \\
\hline C14 index & -5.68 & 2.7 & 0.048 & 2.23 & 1.26 & 0.078 \\
\hline C18 index & -0.96 & 0.27 & 0.724 & -12.16 & 5.84 & 0.040 \\
\hline Total index & -2.11 & 0.24 & 0.385 & -12.81 & 4.53 & 0.008 \\
\hline SFA & 0.14 & 0.01 & 0.916 & 5.41 & 2.4 & 0.031 \\
\hline MUFA & -0.708 & 1.33 & 0.596 & -8.09 & 2.72 & 0.004 \\
\hline
\end{tabular}

Bold in the table indicates P-values lower than 0.05

SFA saturated fatty acid, MUFA monounsaturated fatty acid, SEM standard error of the means

\section{Phenotypic correlations}

The phenotypic correlations between milk component and fatty acid traits in Borgou cows are presented in Table 6. In Borgou, the fat percentage showed significantly $(\mathrm{P}<0.05)$ positive correlation with protein content (0.54), C14 index (0.45), C18:1 cis-9 (0.24), and MUFA (0.28) and negative correlations with C16:0 (-0.22) and PUFA (-0.25). The C14:1 cis-9 showed positive and moderate correlation $(\mathrm{P}<0.01)$ with $\mathrm{C} 14$ index (0.33) and $\mathrm{C} 18$ index (0.31) but a negative correlation with $\mathrm{C} 16: 0(-0.37, \mathrm{P}<0.001)$. The correlations of $\mathrm{C} 16: 0$ were negative between all the traits except for SFA (0.48), (Table 6). The C18:2 cis-9, cis-12 was negatively correlated $(\mathrm{P}<0.01)$ with C18:1 cis-9, SFA and MUFA. The C18:1 cis-9 showed high significant and positive correlation $(\mathrm{P}<0.001)$ with $\mathrm{C} 18$ index, total unsaturation index and MUFA. On the other hand, high significant and negative correlation $(\mathrm{P}<0.001)$ was observed between C18:1 cis-9 and SFA. The C14 index showed moderate and positive correlation $(\mathrm{P}<0.05)$ with C18 index (0.27), total unsaturation index (0.52) and with MUFA (0.38). The total index showed high positive correlation $(\mathrm{P}<0.001)$ with MUFA $(0.88)$ and negative correlation $(\mathrm{P}<0.001)$ with SFA $(-0.71)$.

Table 7 presents the phenotypic correlations between milk component and fatty acid traits in White Fulani cows. Fat content showed high significant and positive correlation $(\mathrm{P}<0.01)$ with protein content, $\mathrm{C} 14: 1 \mathrm{cis}-9$ and $\mathrm{C} 14$ index (Table 7). The protein percentage was moderately and positively correlated $(\mathrm{P}<0.05)$ with $\mathrm{C} 14: 1$ cis- 9 and $\mathrm{C} 14$ index. The $\mathrm{C} 18: 2$ cis-9-12 was negatively correlated $(\mathrm{P}<0.05)$ with $\mathrm{C} 18$ index $(-0.24)$ and PUFA $(-0.42)$ while positively correlated $(\mathrm{P}<0.05)$ to C14 index (0.24) and SFA (0.31). The total index showed high positive correlation $(\mathrm{P}<0.001)$ with MUFA $(0.94)$, negative correlation $(\mathrm{P}<0.0 .01)$ with SFA $(-0.82)$ and PUFA $(-0.34)$ (Table 7).

\section{Discussion}

\section{Effect of breed and geographical regions}

In the present study, we analyzed the milk and fatty acid composition as well as fatty acid unsaturation indices in indigenous White Fulani and Borgou cows in Benin. White Fulani produced milk with high $(\mathrm{P}<0.001)$ fat content than Borgou. Significant differences between breeds were observed for individual fatty acids, fatty acid unsaturation indices and fatty acid groups. The milk of Borgou breed had higher MUFA and PUFA content and $\mathrm{C} 18$ and total indices than White Fulani. Breed effect on fatty acid composition was reported in the meat of Borgou and White Fulani cattle in Benin [38], in the milk of South African indigenous cattle breeds [39] and Italian Holstein-Friesian, Brown Swiss, Simmental and Alpine cattle breeds [40]. In this study, White Fulani presented the highest content of SFA (68.19 vs. $58.46 \%, \mathrm{P}<0.001)$ and the lowest content of PUFA (12.40 vs. $19.56 \%, \mathrm{P}<0.001)$ compared to Borgou, and similar MUFA content (19.41 vs. $21.98 \%, \mathrm{P}>0.05)$ for both breeds. These results corroborate previous studies in Benin indicating that the meat of White Fulani bulls had higher SFA content (49.68\%) compared to Borgou (43.03\%) and similar MUFA content (33.60\% vs. 33.43\%) [38]. In the current study, Borgou presented higher $\mathrm{C} 18$ index $(\mathrm{P}<0.001)$ and total unsaturation index $(\mathrm{P}<0.05)$ than White Fulani. The unsaturation or desaturation index of a specific fatty acid represents the ratio of the concentration of the monounsaturated product to the sum of the monounsaturated and the saturated substrate [22]. Considering human health aspects, increasing the amount of unsaturated fatty acids as well as unsaturation indices is an important selection objective [10]. Borgou presented lower SFA (58.46\%) than the values of $64 \%, 63.7 \% ; 60.9 \%$ and $71.9 \%$ reported in milk of free-ranging South African indigenous Boran, Nguni, Tuli and Afrikaner cattle breeds, respectively [39]. Moreover, Borgou and White Fulani presented lower MUFA content (21.98\% and $19.41 \%$, respectively) than South African indigenous cattle (MUFA content ranged from $25.7 \%$ in Afrikaner 


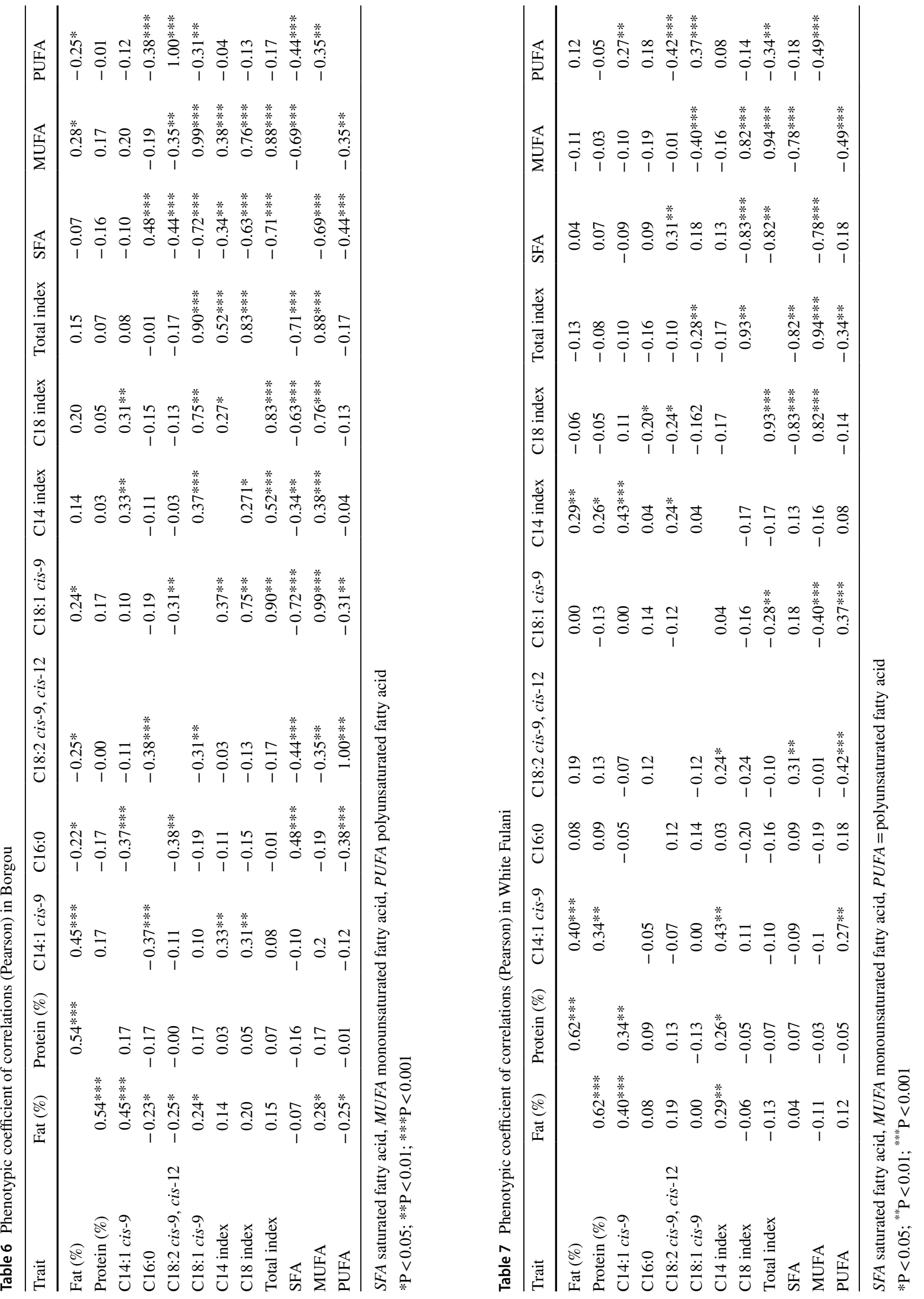


to $36.5 \%$ in Tuli breed) [39]. On the contrary, Borgou and White Fulani produced milk with C18:2 cis-9, cis-12 of $15.84 \%$ and $9.85 \%$ respectively, much higher than the range of 1.3 to $1.7 \%$ observed in South African indigenous Boran, Nguni, Tuli and Afrikaner [39]. The difference in C18:2 cis9, cis-12 content between Borgou/White Fulani and South African indigenous cattle may be due to the lower sample size in their study being 6 Boran, 9 Nguni, 10 Tuli and 6 Afrikaner [39]. Several factors influence milk fatty acid composition such as species, breed, individual variability, nutrition, stage of lactation, parity and season [40, 41]. Studied animals were raised in the traditional system on natural grazing without concentrate supplementation and they were sampled at the same period eliminating the effect of season. The observed differences between breeds would therefore be due to their genetic background. However, the differences in fatty acid composition between the two breeds could also be due to the fatty acid composition of the forage consumed by the cows on natural grazing. The White Fulani and Borgou are raised in different agro-ecological zones with different floristic composition. The White Fulani cattle are found in the Northern part of Benin while Borgou cattle are found throughout the country. The forage species and variety, climate and stage of growth are important factors that affect fatty acid content and composition of forage [38, 42] and can therefore affect the milk fatty acid composition of the cows. The Borgou cows from the North of Benin produced milk with higher C14:1 cis-9, C18:1 cis-9, C14 unsaturation index, $\mathrm{C} 18$ unsaturation index, total unsaturation index and MUFA contents than Borgou cows from the South of Benin. Consequently, milk from Borgou cows raised in the North of Benin seems to be healthier than from Borgou cows raised in the South of Benin due to its higher content of MUFA and higher unsaturation indices.

The suggested favorable combination of bovine milk fatty acid composition for human health enhancement is 30\% SFA, 60\% MUFA, and 10\% PUFA [43]. In the present study, the milk fatty acid compositions were 58.48\% SFA, 21.98\% MUFA and 19.56 PUFA for Borgou and 68.19\% SFA, $19.41 \%$ MUFA and $12.40 \%$ PUFA for White Fulani. It's clear that the current milk fatty acid composition of Borgou and White Fulani is far from optimal and there is need for modification towards an ideal profile. Linoleic acid (a PUFA) and oleic acid (a MUFA) have been associated with decreased serum total cholesterol and low-density lipoprotein cholesterol levels and reduced risk of coronary heart diseases in humans [44]. Oleic acid has anticancer and antiatherogenic properties [45]. Linoleic acid, an essential fatty acid in the omega- 6 family is associated with reduced incidence of type 2 diabetes through its ability to improve sensibility to insulin [46]. On the other hand, palmitic acid (C16:0), considered as hypercholesterolemic is responsible for the increase in the concentration of low density lipoproteins (LDL) that are associated with coronary heart diseases in humans [47]. Borgou milk with its higher linoleic acid, oleic acid and lower total SFA contents as compared to White Fulani with higher total SFA and palmitic acid contents, may be preferred by consumers than White Fulani milk.

\section{Effects of SCD1 A293V and DGAT1 K232A polymorphisms}

The frequencies of $S C D 1293 \mathrm{~V}$ were 0.84 and 0.94 in Borgou and White Fulani, respectively. A higher frequency of the $\mathrm{V}$ allele (0.82) is also reported in Italian Brown cows [15] while a higher frequency of the A allele has been reported in Dutch Holstein-Friesian heifers (0.73), Italian Holsteins (0.57), and Canadian Jersey cows (0.80) [10, $20,22]$. The difference in $S C D 1 \mathrm{~A} 293 \mathrm{~V}$ allele frequencies between the studied indigenous breeds and western breeds can be explained by a breed specific effect. The SCD1 AV genotype was associated with higher $\mathrm{C} 14$ and total unsaturation index compared to the VV genotype in Borgou breed. This result did not agree with Conte et al. [15] who associated SCD1 VV genotype with higher C14 index in Italian Brown cows. Moreover, Kgwatalala et al. [20] showed that the AA genotype of $S C D 1$ was associated with higher C14 index. The effect of SCD1 A293V genotypes on C14 index seems to vary from one breed to another. In the current study, $S C D 1$ genotypes did not significantly affect protein or fat percentage in Borgou (Table 4) which is similar to the results of Schennink et al. [10] in Dutch Holstein-Friesian heifers. However, in the present study, the $S C D 1 \mathrm{~V}$ allele had significant negative association $(-5.68 \%, \mathrm{P}<0.05)$ with $\mathrm{C} 14$ index compared to the A allele in Borgou. The allele A of $S C D 1$ is therefore significantly associated with $5.68 \%$ more $\mathrm{C} 14$ index in Borgou. The positive significant association between the allele A of SCD1 and C14:1 cis-9 and $\mathrm{C} 14$ index has been reported previously [10, 20, 22]. However, allele A of $S C D 1$ did not show significant effect on C14:1 cis-9 in this study. This may be explained by the large sample sizes used in the other studies, namely 1725 Dutch Holstein-Friesian heifers [10], 297 Italian Holstein Friesian cows [22] and 525 Canadian Jersey cows [20]. Also, significant associations of the SCD1 A293V polymorphism with $\mathrm{C} 10$ index, $\mathrm{C} 12$ index, $\mathrm{C} 16$ index and $\mathrm{C} 18$ index has been reported $[10,20]$. However, no significant effect of $S C D 1$ polymorphism was observed for $\mathrm{C} 18$ index in this study.

The frequencies of DGAT1 $232 \mathrm{~K}$ were 0.77 and 0.92 in Borgou and White Fulani breeds respectively. A higher frequency of the $\mathrm{K}$ allele in Borgou and White Fulani breeds in Benin [32] and in Sudanese Butana and Kenana cattle breeds have been reported previously [31]. However, a lower frequency of DGAT1 K allele (0.40) was reported in Dutch Holstein-Friesian heifers [10]. In this study, the DGATl K 
allele was associated with lower $\mathrm{C} 18$ index $(\mathrm{P}<0.05)$, total unsaturation index $(\mathrm{P}<0.01)$, and MUFA $(\mathrm{P}<0.01)$, and with higher SFA $(\mathrm{P}<0.05)$ in White Fulani breed. These results are similar to a reported by Schennink et al. [21], who studied 1762 Dutch Holstein Friesian cows and found that the DGAT1 $232 \mathrm{~K}$ allele was associated with more saturated fatty acid. However, no significant effect of DGAT1 232K allele on $\mathrm{C} 18$ and total unsaturation indices was found by Schennink et al. [21]. Similar to our data, Schennink et al. [10] showed that the DGATI K allele was associated with lower $\mathrm{C} 18$ and total unsaturation indices. The majority of milk fatty acids are present in the form of triacylglycerols and the DGAT1 enzyme plays an important role during the last step of triglyceride synthesis. The DGATl K232A polymorphism was reported to have significant association with milk fatty acid composition and unsaturation indices [15]. However, we did not observed significant association of DGAT1 K232A polymorphism with individual fatty acids but significant associations with SFA and MUFA was observed. This is conceivable because the effect of DGAT1 on fatty acid composition and saturation may be due to a higher activity and alteration of specificity of DGAT1 enzyme [21] which may vary between breeds. The discussion of our results on DGAT1 K232A polymorphism and fatty acid traits was limited to western dairy breeds because of the scarcity of data on African indigenous cattle breeds.

\section{Phenotypic correlations}

The Pearson correlation coefficient between total SFA and total PUFA was negative and moderate $(-0.44)$ in Borgou. Similar correlation $(-0.34)$ has been observed between total SFAs and total PUFAs in Canadian Holsteins [48]. The fat percentage showed positive correlations with C14:1 cis-9 (0.45) and C18:2 cis-9, cis-12 (0.24) and negative correlation with total PUFAs (-0.25) in Borgou. Accordingly, an increase in the fat content of Borgou milk will lead to slightly higher C14:1 cis- 9 and C18:2 cis- 9 , cis- 12 contents and decreased total PUFA content. The fat content positively affect the price of milk in developed countries, therefore increasing PUFAs (decreasing fat content) should have negative economic impact [49]. However, in the African context, and in Benin in particular, the price of milk is not influenced by its fat content and hence decreasing total fat content for increased PUFAs in Borgou milk will be beneficial for human health and will not negatively affect farm incomes. On the contrary, increasing fat and protein percentage in White Fulani breed will lead to slightly higher increase in C14:1 cis-9 and C14 index due to the moderate positive correlation observed between the traits (Table 6). In the present study, C16:0, showed significant and negative correlations with fat percentage (-0.23), C14:1 cis-9 $(-0.37), \mathrm{C} 18: 2$ cis-9, cis-12 (-0.38) and positive correlation with total SFA
(0.48) in Borgou breed. This implies that decreasing C16:0 will lead to increase in fat percentage, C14:1 cis-9, C18:2 cis-9, cis-12 and decrease in total SFAs in Borgou which would be an important selection goal.

\section{Conclusion}

This study has revealed significant differences in milk components, milk fatty acid composition and unsaturation indices between White Fulani and Borgou indigenous cattle breeds in Benin. The Borgou milk contained higher linoleic acid, higher oleic acid and lower total SFA compared to White Fulani which are beneficial traits for human health. The SCDI AV genotype was associated with higher $\mathrm{C} 14$ and total indices; and the $S C D 1 \mathrm{~V}$ allele was associated with decrease in $\mathrm{C} 14$ index in Borgou. In White Fulani breed, the $S C D 1$ VV genotype was associated with lower C18:1 cis-9 content while the DGAT1 $K$ allele was associated with increased total SFA, and decreased $\mathrm{C} 18$ unsaturation index, total unsaturation index and total MUFA. SCD1 A293V and DGAT1 K232A polymorphisms may serve as potential genetic markers in a breeding program to improve milk fatty acids traits in indigenous cattle breeds in Benin. However, further studies with a large population of the Borgou and White Fulani breeds are needed to better understand the genetic variability of their milk fatty acids and association with genetic polymorphisms in $S C D 1$ and $D G A T l$ genes.

Acknowledgements The authors are grateful to the Molecular Genetics and Genome Analysis Laboratory of Abomey-Calavi University (Benin Republic) for offering the facilities and the technical supports towards the DNA extraction. We also thank the field assistants as well as the cattle herdsmen for facilitating the sampling.

Author contributions IH, FS, IAKY and EMIA designed the study. IH performed the laboratory analysis and wrote the first draft of the paper.

Funding This study was supported by the BecA-ILRI Hub through the Africa Biosciences Challenge Fund (ABCF) program. The ABCF Program is funded by the Australian Department for Foreign Affairs and Trade (DFAT) through the BecA-CSIRO partnership; the Syngenta Foundation for Sustainable Agriculture (SFSA); the Bill \& Melinda Gates Foundation (BMGF); the UK Department for International Development (DFID) and the Swedish International Development Cooperation Agency (Sida). Sample collection and DNA extraction were supported by the Pan African University Institute of Basic Sciences, Technology and Innovation (PAUSTI) based at Jomo-Kenyatta University of Agriculture and Technology (JKUAT), Kenya.

\section{Compliance with ethical standards}

Conflict of interest The authors have no conflict of interest to declare.

Ethics approval This Manuscript does not report studies involving human participants, human data or human tissue. The use of animals 
and sample collection procedures were in accordance with the ethical standards and were approved by the Livestock Research Subdivision (LRS) ethics committee in Benin. The farmers gave a written consent prior to blood and milk sample collection.

Open Access This article is distributed under the terms of the Creative Commons Attribution 4.0 International License (http://creativeco mmons.org/licenses/by/4.0/), which permits unrestricted use, distribution, and reproduction in any medium, provided you give appropriate credit to the original author(s) and the source, provide a link to the Creative Commons license, and indicate if changes were made.

\section{References}

1. Rooke JA, Flockhart JF, Sparks NH (2010) The potential for increasing the concentrations of micro-nutrients relevant to human nutrition in meat, milk and eggs. J Agric Sci 148:603-614

2. Jensen RG (2002) The composition of Bovine Milk Lipids: January 1995 to December 2000. J Dairy Sci 85:295-350

3. German JB, Monrad L, Dillard CJ, Xu R (1997) Milk fat composition: targets for alteration of function and nutrition. In: Welch RAS, Burns DJW, Davis SR, Popay AI, Prosser CJ (eds) Milk composition, production, biotechnology. CAB International, Wallingford, pp 35-72

4. Kromhout D, Menotti A, Kesteloot H, Sans S (2002) Prevention of coronary heart disease by diet and lifestyle evidence from prospective cross-cultural, cohort, and intervention studies. Circulation 105:893-898

5. Denke MA (2006) Dietary fats, fatty acids, and their effects on lipoproteins. Curr Atheroscler Rep 8:466-471

6. Glaser C, Heinrich J, Koletzko B (2010) Role of FADS1 and FADS2 polymorphisms in polyunsaturated fatty acid metabolism. Metabolism 59:993-999

7. Yang T, Fang S, Zhang HX, Xu LX, Zhang ZQ, Yuan KT, Xue CL, Yu HL, Zhang S, Li YF, Shi HP, Zhang Y (2013) N-3 PUFAs have antiproliferative and apoptotic effects on human colorectal cancer stem-like cells in vitro. J Nutr Biochem 24:744-753

8. Park BK, Park S, Park JB, Park MC, Min TS, Jin M (2013) Omega-3 fatty acids suppress Th2-associated cytokine gene expressions and GATA transcription factors in mast cells. J Nutr Biochem 24:868-876

9. Prescott SL, Calder PC (2004) N-3 polyunsaturated fatty acids and allergic disease. Curr Opin Clin Nutr Metab Care 7:123-129

10. Schennink A, Heck JML, Bovenhuis H, Visker MHPW, van Valenberg HJF, van Arendonk JAM (2008) Milk fatty acid unsaturation: genetic parameters and effects of stearoyl-CoA desaturase (SCD1) and acyl CoA: diacylglycerol acyltransferase 1 (DGAT1). J Dairy Sci 91:2135-2143

11. Parodi PW (2004) Milk fat in human nutrition. Aust J Dairy Technol 59:3-59

12. Kelsey JA, Corl BA, Collier RJ, Bauman DE (2003) The effect of breed, parity, and stage of lactation on conjugated linoleic acid (CLA) in milk fat from dairy cows. J Dairy Sci 86:2588-2597

13. Drackley JK, Beaulieu AD, Elliott JP (2001) Responses of milk fat composition to dietary fat or nonstructural carbohydrates in holstein and jersey cows 1. J Dairy Sci 84:1231-1237

14. Sol Morales M, Palmquist DL, Weiss WP (2000) Milk fat composition of holstein and jersey cows with control or depleted copper status and fed whole soybeans or tallow 1. J Dairy Sci 83:2112-2119

15. Conte G, Mele M, Chessa S, Castiglioni B, Serra A, Pagnacco G, Secchiari P (2010) Diacylglycerol acyltransferase 1, stearoyl-CoA desaturase 1, and sterol regulatory element binding protein 1 gene polymorphisms and milk fatty acid composition in Italian Brown cattle. J Dairy Sci 93:753-763

16. Kgwatalala PM, Ibeagha-Awemu EM, Hayes JF, Zhao X (2009) Stearoyl-CoA desaturase $13^{\prime}$ UTR SNPs and their influence on milk fatty acid composition of Canadian Holstein cows. J Anim Breed Genet 126:394-403

17. Grisart B, Farnir F, Karim L, Cambisano N, Kim J-J, Kvasz A et al (2004) Genetic and functional confirmation of the causality of the DGAT1 K232A quantitative trait nucleotide in affecting milk yield and composition. Proc Natl Acad Sci USA 101:2398-2403

18. Streit M, Neugebauer N, Meuwissen THE, Bennewitz J (2011) Short communication: Evidence for a major gene by polygene interaction for milk production traits in German Holstein dairy cattle. J Dairy Sci 94:1597-1600

19. Molee A, Duanghaklang N, Na-Lampang P (2012) Effects of Acyl-CoA: diacylglycerol acyl transferase 1 (DGAT1) gene on milk production traits in crossbred Holstein dairy cattle. Trop Anim Health Prod 44:751-755

20. Kgwatalala PM, Ibeagha-Awemu EM, Mustafa AF, Zhao X (2009) Influence of stearoyl-coenzyme A desaturase 1 genotype and stage of lactation on fatty acid composition of Canadian Jersey cows. J Dairy Sci 92:1220-1228

21. Schennink A, Stoop WM, Visker MHPW, Heck JML, Bovenhuis H, Van Der Poel J-J, Van Valenberg HJF, Van Arendonk JAM (2007) DGAT1 underlies large genetic variation in milk-fat composition of dairy cows. Anim Genet 38:467-473

22. Mele M, Conte G, Castiglioni B, Chessa S, Macciotta NPP, Serra A, Buccioni A, Pagnacco G, Secchiari P (2007) Stearoylcoenzyme A desaturase gene polymorphism and milk fatty acid composition in Italian holsteins. J Dairy Sci 90:4458-4465

23. Grisart B, Coppieters W, Farnir F, Karim L, Ford C (2002) Positional candidate cloning of a QTL in dairy cattle: identification of a missense mutation in the bovine DGAT gene with major effect on milk yield and composition. Genome Res 12:222-231

24. Sanders K, Bennewitz J, Reinsch N, Thaller G, Prinzenberg E-M, Kühn C, Kalm E (2006) Characterization of the DGAT1 mutations and the CSN1S1 promoter in the German Angeln dairy cattle population. J Dairy Sci 89:3164-3174

25. Gautier M, Capitan A, Fritz S, Eggen A, Boichard D, Druet T (2007) Characterization of the DGAT1 K232A and variable number of tandem repeat polymorphisms in French dairy cattle. J Dairy Sci 90:2980-2988

26. Näslund J, Fikse WF, Pielberg GR, Lundén A (2008) Frequency and effect of the Bovine Acyl-CoA:Diacylglycerol acyltransferase 1 (DGAT1) K232A polymorphism in Swedish Dairy Cattle. J Dairy Sci 91:2127-2134

27. Bennewitz J, Reinsch N, Paul S, Looft C, Kaupe B, Weimann C, Erhardt G, Thaller G, Kühn C, Schwerin M, Thomsen H, Reinhardt F, Reents R, Kalm E (2004) The DGAT1 K232A mutation is not solely responsible for the milk production quantitative trait locus on the bovine chromosome 14. J Dairy Sci 87:431-442

28. Chung M, Ha S, Jeong S, Bok J, Cho K, Baik M, Choi Y (2000) Cloning and characterization of bovine stearoyl CoA desaturase1 cDNA from adipose tissues. Biosci Biotechnol Biochem 64:1526-1530

29. Pereira SL, Leonard AE, Mukerji P (2003) Recent advances in the study of fatty acid desaturases from animals and lower eukaryotes. Prostaglandins Leukot Essent Fat Acids 68:97-106

30. Kaupe B, Winter A, Fries R, Erhardt G (2004) DGAT1 polymorphism in Bos indicus and Bos taurus cattle breeds. J Dairy Res 71:182-187

31. Rahmatalla S, ReiBmann M, Mueller U, Brockmann G (2015) Identification of genetic variants influencing milk production traits in sudanese dairy cattle. Res J Anim Sci 9:12-22 
32. Houaga I, Muigai AWT, Kyallo M, Githae D, Youssao IAK, Stomeo F (2017) Effect of breed and diacylglycerol acyltransferase 1 gene polymorphism on milk production traits in Beninese White Fulani and Borgou cows. Glob J Anim Breed Genet 5:403-412

33. Latimer W (2012) Official method of analysis of AOAC international, 19th edn. AOAC International, Maryland

34. Strehmel N, Hummel J, Erban A, Strassburg K, Kopka J (2008) Retention index thresholds for compound matching in GC-MS metabolite profiling. J Chromatogr B 871(2):182-190

35. Sambrook JF, Russell DW (2001) Molecular cloning: a laboratory manual, vol 1, 3rd edn. Cold Spring Harbor Lab Press, New York

36. Raymond M, Rousset F (2001) GENEPOP. Population genetics software and ecumenicism. J Hered 86:248-249

37. Marchitelli C, Contarini G, De Matteis G, Crisà A, Pariset L, Scatà MC, Catillo G, Napolitano F, Moioli B (2013) Milk fatty acid variability: effect of some candidate genes involved in lipid synthesis. J Dairy Res 80:165-173

38. Salifou CFA, Dahouda M, Houaga I, Picard B, Hornick JL, Micol $D$ et al (2013) Muscle characteristics, meat tenderness and nutritional qualities traits of Borgou, Lagunaire and Zebu Fulani Bulls raised on natural pasture in Benin. Int J Anim Vet Adv 5:143-155

39. Myburgh J, Osthoff G, Hugo A, de Wit M, Nel K, Fourie D (2012) Comparison of the milk composition of free-ranging indigenous African cattle breeds. South African J Anim Sci 42:1-14

40. Gottardo P, Penasa M, Righi F, Lopez-villalobos N, Cassandro M, De Marchi M (2017) Fatty acid composition of milk from Holstein- Friesian, Brown Swiss, Simmental and Alpine Grey cows predicted by mid-infrared spectroscopy. Ital J Anim Sci $16(3): 380-389$
41. Poulsen NA, Gustavsson F, Glantz M, Paulsson M, Larsen LB, Larsen MK (2012) The influence of feed and herd on fatty acid composition in 3 dairy breeds (Danish Holstein, Danish Jersey, and Swedish Red). J Dairy Sci 95:6362-6371

42. Kalač P, Samková E (2010) The effects of feeding various forages on fatty acid composition of bovine milk fat: a review. Czech J Anim Sci 55:521-537

43. Hayes KC, Khosla P (1992) Dietary fatty acid thresholds and cholesterolemia. FASEB J 6:2600-2607

44. Mensink RP, Zock PL, Kester ADM, Katan MB (2003) Effects of dietary fatty acids and carbohydrates on the ratio of serum total to HDL cholesterol and on serum lipids and apolipoproteins: a meta-analysis of 60. Am J Clin Nutr 77:1146-1155

45. Haug A, Høstmark AT, Harstad OM (2007) Bovine milk in human nutrition-a review. Lipids Health Dis 6:1-16

46. Hu FB, Manson JE, Willett WC (2001) Types of dietary fat and risk of coronary heart disease: a critical review. J Am Coll Nutr 20:5-19

47. Rotta PP, Do Prado IN, Do Prado RM, Moletta JL, Silva RR, Perotto D (2009) Carcass characteristics and chemical composition of the Longissimus muscle of Nellore, Caracu and HolsteinFriesian bulls finished in a feedlot. Asian-Australasian J Anim Sci 22:598-604

48. Ibeagha-Awemu EM, Akwanji KA, Beaudoin F, Zhao X (2014) Associations between variants of FADS genes and omega- 3 and omega-6 milk fatty acids of Canadian Holstein cows. BMC Genet $15: 25$

49. Arnould VM, Soyeurt H (2009) Genetic variability of milk fatty acids. J Appl Genet 50:29-39 